\title{
ONO-8590580, a Novel GABA $A 5$ Negative Allosteric Modulator Enhances Long-Term Potentiation and Improves Cognitive Deficits in Preclinical Models
}

\author{
Soichi Kawaharada, Miki Nakanishi, Nobuto Nakanishi, Keisuke Hazama, Masato Higashino, \\ Tetsuya Yasuhiro, Arwel Lewis, Gary S. Clark, Mark S. Chambers, Scott A. Maidment, \\ Seishi Katsumata, and Shuji Kaneko \\ Discovery Research Laboratories I (So.K., M.N., N.N., K.H., T.Y., Se.K.) and Medicinal Chemistry Research Laboratories (M.H.), \\ ONO Pharmaceutical Co., Ltd., Shimamoto-cho, Mishima-gun, Osaka, Japan; Charles River Laboratories International, Inc., \\ Saffron Walden, Essex, United Kingdom (A.L., G.S.C., M.S.C., S.A.M.); and Department of Molecular Pharmacology, Graduate \\ School of Pharmaceutical Sciences, Kyoto University, Kyoto, Japan (So.K., Sh.K.)
}

Received December 29, 2017; accepted April 17, 2018

\begin{abstract}
$\mathrm{GABA}_{\mathrm{A}}$ receptors containing $\alpha 5$ subunits $\left(\mathrm{GABA}_{\mathrm{A}} \alpha 5\right)$ are highly expressed in the hippocampus and negatively involved in memory processing, as shown by the fact that $\mathrm{GABA}_{\mathrm{A}}$ $\alpha 5$-deficient mice show higher hippocampus-dependent performance than wild-type mice. Accordingly, small-molecule $\mathrm{GABA}_{\mathrm{A}} \alpha 5$ negative allosteric modulators (NAMs) are known to enhance spatial learning and memory in rodents. Here we introduce a new, orally available $\mathrm{GABA}_{\mathrm{A}} \alpha 5$ NAM that improves hippocampal functions. ONO-8590580 [1-(cyclopropylmethyl)-5-fluoro-4-methyl$\mathrm{N}$-[5-(1-methyl-1H-imidazol-4-yl)-2-pyridinyl]-1H-benzimidazol-6amine] binds to the benzodiazepine binding sites on recombinant human $\alpha 5$-containing $\mathrm{GABA}_{\mathrm{A}}$ receptors with a $K_{\mathrm{i}}$ of $7.9 \mathrm{nM}$, and showed functionally selective $\mathrm{GABA}_{\mathrm{A}} \alpha 5$ NAM activity for GABAinduced $\mathrm{Cl}^{-}$channel activity with a maximum $44.4 \%$ inhibition and an $\mathrm{EC}_{50}$ of $1.1 \mathrm{nM}$. In rat hippocampal slices, tetanusinduced long-term potentiation of CA1 synapse response was
\end{abstract}

significantly augmented in the presence of $300 \mathrm{nM}$ ONO8590580. Orally administered ONO-8590580 (1-20 mg/kg) dose-dependently occupied hippocampal $\mathrm{GABA}_{\mathrm{A}} \alpha 5$ in a range of $40 \%-90 \%$ at 1 hour after intake. In the rat passive avoidance test, ONO-8590580 (3-20 mg/kg, by mouth) significantly prevented (+)-MK-801 hydrogen maleate (MK-801)-induced memory deficit. In addition, ONO-8590580 (20 mg/kg, p.o.) was also effective in improving the cognitive deficit induced by scopolamine and MK-801 in the rat eight-arm radial maze test with equal or greater activity than $0.5 \mathrm{mg} / \mathrm{kg}$ donepezil. No anxiogenic-like or proconvulsant effect was associated with ONO-8590580 at $20 \mathrm{mg} / \mathrm{kg}$ p.o. in the elevated plus maze test or pentylenetetrazole-induced seizure test, respectively. In sum, ONO-8590580 is a novel $\mathrm{GABA}_{\mathrm{A}} \alpha 5$ NAM that enhances hippocampal memory function without an anxiogenic or proconvulsant risk.

\section{Introduction}

Because of the advent of this rapidly aging society, the number of adults with senile dementias, such as Alzheimer's disease (AD), has increased (Akagi et al., 2015). Currently approved pharmacological treatments for $\mathrm{AD}$ are limited to cholinesterase inhibitors as well as the $N$-methyl-D-aspartate (NMDA) receptor antagonist, which acts on the glutamatergic pathway (Farlow et al., 2008). The limited efficacy of these drugs highlights the need for better treatment. Despite the tremendous efforts in search of disease-modifying agents focusing on the $\beta$-amyloid or tau pathways, none are clinically

This research was funded by ONO Pharmaceutical Co., Ltd. (Osaka, Japan) https://doi.org/10.1124/jpet.117.247627. available. Therefore, a strong cognitive enhancer with a novel mode of action is still globally desirable.

GABA is a major inhibitory neurotransmitter in the adult brain. In patients with $\mathrm{AD}$ as well as in transgenic $\mathrm{AD}$ mouse models, altered GABAergic function has been reported. Levels of GABA in cerebrospinal fluid (CSF) (Samakashvili et al., 2011) and reactive astrocytes (Jo et al., 2014) are elevated in patients with $\mathrm{AD}$. The $\mathrm{GABA}_{\mathrm{A}}$ receptor containing $\alpha 5$ subunits $\left(\mathrm{GABA}_{\mathrm{A}} \alpha 5\right)$ chloride channel, highly expressed in the hippocampus, which is involved in learning and memory (Quirk et al., 1996), is upregulated in the hippocampus in patients with $\mathrm{AD}$ (Kwakowsky et al., 2018) and in the $5 \mathrm{xFAD}$ mouse, a transgenic model for $\mathrm{AD}$ (Wu et al., 2014). GABA $\alpha 5$-deficient mice show improved performance in the water

ABBREVIATIONS: AD, Alzheimer's disease; BZ, benzodiazepine; CSF, cerebrospinal fluid; DMSO, dimethylsulfoxide; fEPSP, field excitatory postsynaptic potential; FG-7142, $N$-methyl- $\beta$-carboline-3-carboxamide; $\mathrm{GABA}_{\mathrm{A}} \alpha 5, \mathrm{GABA}_{\mathrm{A}}$ receptors containing $\alpha 5$ subunits; HEK293, human embryonic kidney 293; L-655,708, $\mathrm{C}_{18} \mathrm{H}_{19} \mathrm{~N}_{3} \mathrm{O}_{4}$; LTP, long-term potentiation; MK-801, (+)-MK-801 hydrogen maleate; NAM, negative allosteric modulator; NMDA, $\mathrm{N}$-methyl-D-aspartate; ONO-8590580, 1-(cyclopropylmethyl)-5-fluoro-4-methyl- $\mathrm{N}$-[5-(1-methyl-1H-imidazol-4-yl)-2-pyridinyl]$1 \mathrm{H}$-benzimidazol-6-amine; PAM, positive allosteric modulator; PBS, phosphate-buffered saline; PTZ, pentylenetetrazole; SPA, scintillation proximity assay. 
maze test for studying spatial learning compared with wildtype mice (Collinson et al., 2002). Thus, the overactivation of the $\mathrm{GABA}_{\mathrm{A}} \alpha 5$-mediated signaling pathway should contribute to the inhibition of neuronal activity and impairment of learning and memory in patients with $\mathrm{AD}$. Therefore, agents with $\mathrm{GABA}_{\mathrm{A}} \alpha 5$ inhibitory activity are expected to improve cognitive disorders like AD.

Studies in molecular genetic (mice with a point mutation in the $\mathrm{GABA}_{\mathrm{A}} \alpha$ subunit) or pharmacological approaches suggest that $\mathrm{GABA}_{\mathrm{A}} \alpha 1$ mediates the sedative effects of diazepam, whereas GABA $_{\mathrm{A}} \alpha 2$ and $\alpha 3$ accounts for anxiolytic and myorelaxant effects, respectively (Rudolph et al., 1999; McKernan et al., 2000; Rudolph and Möhler, 2004; Atack et al., 2005). The contribution of each subtype for the physiologic function has been elucidated by the genetically modified mice functionally lacking the diazepam binding site of the $\alpha 1, \alpha 2, \alpha 3$, or $\alpha 5$ subtype. These results suggest that $\alpha 1$ is responsible for the proconvulsant effect (Vergnes et al., 2001) and $\alpha 2 / 3$ for the anxiogenic effect (Horowski and Dorrow, 2002) of nonselective $\mathrm{GABA}_{\mathrm{A}}$ negative allosteric modulators (NAMs). Whereas $\mathrm{GABA}_{\mathrm{A}}$ positive allosteric modulators (PAMs) binding to the benzodiazepine (BZ) site, such as diazepam, increase the GABA response through $\mathrm{GABA}_{\mathrm{A}}$ $\alpha 1, \alpha 2, \alpha 3$, or $\alpha 5$ ( $\alpha 4$ and $\alpha 6$ are diazepam insensitive), nonselective NAMs such as DMCM (methyl-6,7-dimethoxyl-4ethyl-carboline-3-carboxylate) and $N$-methyl- $\beta$-carboline-3carboxamide (FG-7142) decrease GABA response, resulting in a membrane depolarization and increased neuronal excitability (Haefely et al., 1993). Therefore, the opposing effects of PAMs and NAMs at the molecular level are reflected behaviorally in that NAMs are anxiogenic and proconvulsant effects (Haefely et al., 1993). The anxiogenic and proconvulsant liabilities of the nonselective NAMs prevent clinical application (Dorow et al., 1983). It was therefore hypothesized that a $\mathrm{GABA}_{\mathrm{A}} \alpha 5$-selective NAM should improve cognitive impairment without anxiogenic and proconvulsant effects.

The BZ binding site, an allosteric site on the $\mathrm{GABA}_{\mathrm{A}}$ receptor, has the potential to obtain $\mathrm{GABA}_{\mathrm{A}}$ subtype-selective PAMs and NAMs (Atack, 2011). Approximately 124,000 compounds (Charles River Laboratories International, Inc., Essex, UK) were screened in both receptor binding and FLIPR Functional Assays (Molecular Devices, LLC, San Jose, CA) in human GABA $_{\mathrm{A}} \alpha 5 \beta 3 \gamma 2$ expressing the HEK293 cell line. As a result, a novel structural class of $\mathrm{BZ}$ site ligand with the potential to selectively modulate $\mathrm{GABA}_{\mathrm{A}} \alpha 5$ function was identified. In this study, the efficacy of 1-(cyclopropylmethyl)-5-fluoro-4-methyl$N$-[5-(1-methyl-1H-imidazol-4-yl)-2-pyridinyl]-1H-benzimidazol-6-amine (ONO-8590580), a GABA $\alpha 5$ NAM with a novel chemotype, which was obtained after lead optimization from hit compounds, was evaluated.

\section{Materials and Methods}

Compounds. ONO-8590580 (Fig. 1) (purity, $\geq 95 \%$ ) was synthesized at ONO Pharmaceutical Co., Ltd. (Osaka, Japan). Donepezil, (-)-scopolamine hydrobromide trihydrate (scopolamine), (+)-MK801 hydrogen maleate (MK-801), FG-7142, pentylenetetrazole (PTZ), and dimethylsulfoxide (DMSO) were purchased from SigmaAldrich (St. Louis, MO). L-655,708 $\left(\mathrm{C}_{18} \mathrm{H}_{19} \mathrm{~N}_{3} \mathrm{O}_{4}\right)$, a selective GABA $\alpha 5$ ligand (Quirk et al., 1996), was purchased from Santa Cruz Biotechnology (Dallas, TX). ONO-8590580 and L-655,708 used for in vivo studies was first dissolved in DMSO and then added to WellSolve (Celeste Corporation, Tokyo, Japan) and water (final composition ratio of the solution: $2 \%$ DMSO, $20 \%$ WellSolve, $78 \%$

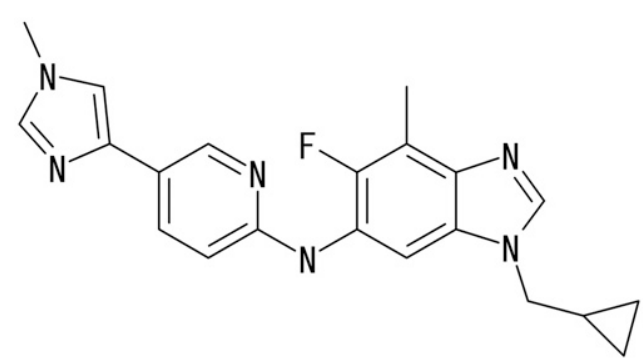

Fig. 1. Chemical structure of ONO-8590580.

water). Scopolamine, MK-801, and PTZ was dissolved in saline. Donepezil was dissolved in water. FG-7142 was suspended in 0.1 vol $\%$ polyoxyethylene (20) sorbitan monooleate (Tween 80; Wako Pure Chemical Industries, Ltd., Osaka, Japan) in saline.

Animals. All experimental procedures were approved by the institutional animal care and use committee of ONO Pharmaceutical Co., Ltd. All efforts were made to minimize the number of animals used and their suffering. Male Sprague Dawley rats (Crl:CD(SD), 6 weeks old; Charles River Laboratories Japan, Inc.) were used in the long-term potentiation (LTP) and in vivo receptor occupancy studies. Male Sprague Dawley rats (Crl:CD(SD), 7 weeks old; Charles River Laboratories Japan, Inc.) were used in the passive avoidance test and the elevated plus maze test. Male Wistar rats (Crlj:WI, 7-9 weeks old; Charles River Laboratories Japan, Inc.) were used for the eight-arm radial maze test. Male ICR mice (Crlj:CD1(ICR), 7-9 weeks old; Charles River Laboratories Japan, Inc.) were used for the PTZ proconvulsant test. Animals were housed in groups of less than five animals/cage in a temperature- and humidity-controlled animal room (temperature, $24 \pm 2{ }^{\circ} \mathrm{C}$; relative humidity, $55 \% \pm 15 \%$ ) under a 12-hour light/dark cycle (light on from 8:00 AM to 8:00 PM). Food and water were available ad libitum.

Cell Cultures. Human GABA $\alpha 1 \beta 3 \gamma 2$ expressing the HEK293 cell line (catalog number CYL3053; Merck Millipore, Burlington, MA), human $\mathrm{GABA}_{\mathrm{A}} \alpha 2 \beta 3 \gamma 2$ expressing the HEK293 cell line (catalog number CYL3072; Merck Millipore), human GABA $\alpha 3 \beta 3 \gamma 2$ expressing the HEK293 cell line (catalog number CYL3068; Merck Millipore), and human $\mathrm{GABA}_{\mathrm{A}} \alpha 5 \beta 3 \gamma 2$ expressing the HEK293 cell line (catalog number CYL3073; Merck Millipore) were cultured at $37^{\circ} \mathrm{C}\left(5 \% \mathrm{CO}_{2}\right.$, 95\% air) until confluence in Dulbecco's modified Eagle's medium/Ham's F-12 medium with L-glutamine (Invitrogen, Carlsbad, CA), supplemented with $10 \%$ fetal bovine serum (Invitrogen), 1\% nonessential amino acids (Invitrogen), $400 \mu \mathrm{g} / \mathrm{ml}$ Geneticin (Invitrogen), $100 \mu \mathrm{g} / \mathrm{ml}$ Hygromycin B (Invitrogen), and $0.625 \mu \mathrm{g} / \mathrm{ml}$ Puromycin (Clontech, Mountain View, CA).

In Vitro Radioligand Binding Studies. The GABA $\alpha 1 \beta 3 \gamma 2$, $\alpha 2 \beta 3 \gamma 2, \alpha 3 \beta 3 \gamma 2$, and $\alpha 5 \beta 3 \gamma 2$ protein used for the scintillation proximity assay (SPA) was derived from membranes produced from the cell line expressing each complex. Membranes were prepared as previously published (Hadingham et al., 1993). Briefly, after routine culture in T175 flasks (CellBIND Surface; Corning Inc., Corning, NY), cells were washed with Dulbecco's phosphate-buffered saline (PBS; Invitrogen), scraped from the flask into PBS, and pelleted by centrifugation $(500 \mathrm{~g})$. The cells were resuspended in $10 \mathrm{mM}$ potassium phosphate at pH 7.4 and homogenized (5000 rpm, 15 seconds) using a Precellys Tissue Homogenizer (Precellys 24-Dual; Bertin Technologies, Thiron-Gardais, France). The homogenates were centrifuged at $48,000 \mathrm{~g}$ for 30 minutes, resuspended, and washed twice. The final resuspension of membranes took place in buffer containing $10 \mathrm{mM}$ potassium phosphate and $100 \mathrm{mM} \mathrm{KCl}$. The protein concentration in membrane preparations was confirmed using a BCA (bicinchoninic acid) Protein Assay Kit (Thermo Fisher Scientific, Waltham, MA).

ONO-8590580 was diluted in $100 \%$ DMSO. For the SPA, $0.5 \mu$ l of ONO-8590580 per well was added to a white-walled, clear-bottomed Matrix 384-well plate (Thermo Fisher Scientific). The assay controls 
used to calculate the percentage of inhibition consisted of DMSO and $100 \mu \mathrm{M}$ flumazenil (final concentration, $2 \mu \mathrm{M}$ ), both $0.5 \mu \mathrm{l}$ per well, for full signal and full block, respectively. Protein $(10 \mu \mathrm{l})$ was added to the plate at a concentration of $2.5 \mu \mathrm{g} /$ well followed by $9.5 \mu \mathrm{l}$ of polyvinyltoluene-wheat germ agglutinin beads at a concentration of $0.2 \mathrm{mg} / \mathrm{well}$. Both protein and bead were diluted to the desired concentration with $10 \mathrm{mM}$ potassium phosphate, $\mathrm{pH}$ 7.4, containing $100 \mathrm{mM} \mathrm{KCl}$. The reagents were preincubated for 30 minutes at room temperature with shaking before initiation of the reaction by the addition of a radioligand. The ability of ONO-8590580 to inhibit the binding of either $\left.30 \mathrm{nM} \mathrm{[}{ }^{3} \mathrm{H}\right]-\mathrm{Ro} 15-1788$ (PerkinElmer LAS GmbH, Rodgau, Germany) to $\mathrm{GABA}_{\mathrm{A}} \alpha 1, \alpha 2$, or $\alpha 3$ or $2 \mathrm{nM}\left[{ }^{3} \mathrm{H}\right]-\mathrm{Ro} 15-4513$ (PerkinElmer LAS GmbH) to $\mathrm{GABA}_{\mathrm{A}} \alpha 5$ was measured. From the $\mathrm{EC}_{50}$, the $K_{\mathrm{i}}$ (inhibitory constant) was calculated from the ChengPrusoff equation (Cheng and Prusoff, 1973), using $K_{\mathrm{d}}$ (dissociation constant) for the binding of $\left[{ }^{3} \mathrm{H}\right]-\mathrm{Ro} 15-1788$ to $\mathrm{GABA}_{\mathrm{A}} \alpha 1, \alpha 2$, and $\alpha 3$ at concentrations of 13,15 , and $15 \mathrm{nM}$, respectively, and for the binding of $\left[{ }^{3} \mathrm{H}\right]-$ Ro $15-4513$ to $\mathrm{GABA}_{\mathrm{A}} \alpha 5$ at a concentration of $2.0 \mathrm{nM}$. $\left[{ }^{3} \mathrm{H}\right]-\mathrm{Ro} 15-17885 \mu \mathrm{l}$ was added at a concentration of $30 \mathrm{nM}$ (final concentration, $6 \mathrm{nM}$ ), giving a final reaction volume of $25 \mu \mathrm{l}$ and a DMSO concentration of $2 \% \mathrm{v} / \mathrm{v}$. The plates were sealed, and the reaction mix was incubated at room temperature for a minimum of 2 hours with gentle agitation on a plate shaker. At the end of the incubation period, the plates were centrifuged for 2 minutes at $1000 \mathrm{rpm}$ prior to reading on a PerkinElmer Microbeta. For each compound, the $\mathrm{EC}_{50}$ and $K_{\mathrm{i}}$ values were determined, the data were entered in Activity Base (IDBS), and the curves were fitted to the mean data. The $Z^{\prime}$ factor values in the binding assays for $\mathrm{GABA}_{\mathrm{A}} \alpha 1$, $\alpha 2, \alpha 3$, and $\alpha 5$ were $0.53,0.53,0.50$, and 0.54 , respectively.

In Vitro Efficacy. Current recordings were performed using PatchXpress (Molecular Devices, LLC) with HEK293 cell lines expressing human $\mathrm{GABA}_{\mathrm{A}} \alpha 1, \alpha 2, \alpha 3$, or $\alpha 5$ subunits associated with $\beta 3 \gamma 2$ subunits. Cells were dissociated from poly-D-lysine-treated tissue culture flasks using a 1:1 mixture of TrypLE (Invitrogen) and Dulbecco's PBS (Invitrogen). The dissociated cells were resuspended in Dulbecco's modified Eagle's medium/Ham's F-12 medium (Invitrogen) supplemented with 10\% fetal bovine serum (Invitrogen) and 1\% nonessential amino acids (Invitrogen), and were allowed to recover for 1 hour at $37^{\circ} \mathrm{C}$ in a humidified incubator with $5 \% \mathrm{CO}_{2}$. At the end of the recovery period, cells were centrifuged at $1000 \mathrm{rpm}$ for 2 minutes, and the pellet was resuspended and diluted to $2.5 \times 10^{6}$ cells $/ \mathrm{ml}$ in a solution (137 mM NaCl, $4 \mathrm{mM} \mathrm{KCl,} 10 \mathrm{mM}$ HEPES, $1.8 \mathrm{mM} \mathrm{CaCl}_{2}$, $1 \mathrm{mM} \mathrm{MgCl}_{2}$, and $10 \mathrm{mM}$ glucose, $\mathrm{pH}$ 7.35). Current responses were recorded in the presence of concentration-matched DMSO $(0.3 \% \mathrm{v} / \mathrm{v})$. Patch pipettes were filled with a solution composed $90 \mathrm{mM} \mathrm{KCl}$, $50 \mathrm{mM} \mathrm{KF}, 11 \mathrm{mM}$ EGTA, $10 \mathrm{mM}$ HEPES, $1 \mathrm{mM} \mathrm{MgCl}_{2}$, and $2 \mathrm{mM}$ $\mathrm{Mg}-\mathrm{ATP}$ ( $\mathrm{pH}$ 7.35). The holding potential was $-60 \mathrm{mV}$. Control GABA responses were first determined at their concentration of GABA giving a current that was $20 \%$ of the maximum $\left(\mathrm{EC}_{20}\right.$ concentration), and a test compound was preapplied for 1 minute prior to the addition of the $\mathrm{EC}_{20}$ concentration of GABA (GABA $\mathrm{A}: \alpha 1,2.4 \mu \mathrm{M} ; \alpha 2,1.5 \mu \mathrm{M} ; \alpha 3,2.3$ $\mu \mathrm{M} ; \alpha 5,0.34 \mu \mathrm{M})$. The test compound and/or GABA were applied for 5 seconds, with 2-minute wash periods between applications. To calculate $\mathrm{EC}_{50}$ values for ONO-8590580, GraphPad Prism software (version 5.01; GraphPad Software Inc., San Diego, CA) was used.

Long-Term Potentiation in Rat Brain Slice. LTP was measured electrophysiologically using a multielectrode array system (MED64; Alpha MED Scientific Inc., Osaka, Japan), as described previously (Tsukamoto et al., 2003). Brain slices were prepared from rats in ice-cold artificial CSF, consisting of $124 \mathrm{mM} \mathrm{NaCl}, 3 \mathrm{mM} \mathrm{KCl}$, $26 \mathrm{mM} \mathrm{NaHCO}_{3}, 2 \mathrm{mM} \mathrm{CaCl}_{2}, 1 \mathrm{mM} \mathrm{MgSO}_{4}, 1.25 \mathrm{mM} \mathrm{KH}_{2} \mathrm{PO}_{4}$ and $10 \mathrm{mM}$ glucose, $\mathrm{pH}$ 7.4. Parasagittal $350-\mu \mathrm{m}$-thick brain slices were cut on a Vibratome sectioning system, and the hippocampal regions were placed at the center of chamber with 64 embedded recording electrodes (MED64; Alpha MED Scientific Inc.) and perfused with 95\% $\mathrm{O}_{2} / 5 \% \mathrm{CO}_{2}$-saturated artificial CSF for at least 1 hour at $32^{\circ} \mathrm{C}$. One of 64 planar microelectrodes was used to stimulate the Schaffer collaterals every 30 seconds. Field excitatory postsynaptic potentials
(fEPSPs) were evoked by the stimulation of a Schaffer collateralcommissural pathway with a stimulus intensity set to produce a half-maximal slope of fEPSP. Synaptic strength was evaluated by measuring changes in the fEPSP slopes. To induce LTP, a $\theta$-burst protocol (four pulses delivered with a frequency of $100 \mathrm{~Hz}$, repeated 10 times with an interval of 200 milliseconds) was used.

In Vivo Receptor Occupancy. The occupancy of the BZ binding site of rat brain $\mathrm{GABA}_{\mathrm{A}} \alpha 5$ was measured using an in vivo $\left[{ }^{3} \mathrm{H}\right]-\mathrm{Ro} 15-$ 4513 binding assay ( $n=3-4$ in each group). ONO-8590580 was orally administered 1 hour before sacrifice. $\left[{ }^{3} \mathrm{H}\right]-$ Ro15-4513 $(1.11 \mathrm{MBq} / \mathrm{kg})$ was administered via the tail vein $(1 \mathrm{ml} / \mathrm{kg}) 10$ minutes before sacrifice. Rats were decapitated, and the brains were rapidly removed and homogenized in ice-cold assay buffer $\left(10 \mathrm{mM} \mathrm{KH}_{2} \mathrm{PO}_{4}, 10 \mathrm{mM} \mathrm{K}_{2} \mathrm{HPO}_{4}\right.$, $100 \mathrm{mM} \mathrm{KCl}$ ). Aliquots of homogenate were filtered and washed over GF/B Glass Fiber Filters (Brandel Inc., Gaithersburg, MD). To determine the amount of nonspecific $\left[{ }^{3} \mathrm{H}\right]-\mathrm{Ro} 15-4513$ binding, a separate group of rats were pretreated for 30 minutes with L-655,708 $(10 \mathrm{mg} / \mathrm{kg}$, i.p.). The signal-to-background ratio was 26 . The amount by which ONO-8590580 reduced the specific binding of $\left[{ }^{3} \mathrm{H}\right]-\mathrm{Ro} 15-4513$ relative to the binding in nontreated rats was defined as the occupancy.

Passive Avoidance Test. The test was performed as described previously (Mitsui et al., 2015). The step-through-type passive avoidance apparatus (Brain Science Idea Co., Ltd., Osaka, Japan) consisted of an illuminated compartment (height, $28 \mathrm{~cm}$; length, $25 \mathrm{~cm}$; width, $11 \mathrm{~cm}$; 700-750 lux) connected to a darkened compartment (height, $30 \mathrm{~cm}$; length, $32 \mathrm{~cm}$; width, $33 \mathrm{~cm}$; 0.03-0.05 lux) by a guillotine door. The experiment consisted of two trials: an acquisition trial and a retention trial ( $n=10-15$ in each group). In the acquisition trial, the rat was placed in the illuminated compartment 30 minutes after administration of MK-801 $(0.1 \mathrm{mg} / \mathrm{kg}$, s.c.) or saline. The guillotine door was then opened, and the rat was allowed to enter the dark compartment. The latency to enter the dark compartment was recorded (step-through latency). Once the rat entered the dark compartment, the door was closed and an electric foot shock was immediately applied (1 second, 2.2 $\mathrm{mA}$ ). On the following day, the rat was placed in the illuminated compartment and again allowed to enter the dark compartment by opening the guillotine door. The step-through latency was once again recorded (retention trial). The maximum cutoff time for step-through latency was set at 300 seconds. During the retention trial, no foot shock was applied. Impairment of learning and memory was defined by a decrease in the time of step-through latency in the retention trial. ONO8590580 or vehicle was administrated 1 hour before both an acquisition trial and a retention trial.

Eight-Arm Radial Maze Test. The test was performed as described previously (Ohta et al., 1993). Briefly, rats $(n=10$ in each group) were fed at a rate of approximately $13 \mathrm{~g} /$ day per rat (approximately $80 \%$ of normal daily feed intake). A daily training trial was carried out more than 10 times to allow the rats to learn how to perform the radial maze test. The trial was judged complete when the rat had chosen all eight baited arms or had spent 10 minutes in the maze. Entry into an arm that had not been previously visited was recorded as a correct response, and re-entry was counted as an error. The last training trial and the test trial to evaluate compounds were carried out in the same day. When a rat made no errors or only one error after the seventh choice in the last training trial, it was considered ready for compound testing. In the test trial, MK-801 and/or scopolamine were subcutaneously administered 0.5 hour before the test trial. ONO-8590580, donepezil, or vehicle was orally administered 1 hour before the trial. A rat was placed on the central hub of the maze and allowed to visit the wells at the end of each of eight arms. The number of errors (the number of repeat entries to arms of the maze already visited) and the latency until the bait of all eight wells had been consumed were counted.

Elevated Plus Maze. Rats ( $n=12$ in each group) were given vehicle, ONO-8590580 (20 mg/kg, p.o.), or, as a positive control, the GABA $_{A}$ nonselective NAM FG-7142 (15 mg/kg, i.p.). After 1 hour, rats were placed in the elevated plus maze for 5 minutes. Light intensity in the open arms was set at 20 lux. A video camera fitted with a 
polarizing lens was mounted above the maze, connected to a tracking and analysis system (EthoVision XT; Noldus Information Technology Inc., Leesburg, VA). The open and closed arms (each $10 \times 50 \mathrm{~cm}$ ) and the central area $(10 \times 10 \mathrm{~cm})$ of the plus maze were defined using the tracking system. The effect of ONO-8590580 on the time spent on the open arms was assessed.

PTZ Proconvulsant Test. Mice ( $n=8$ in each group) were intraperitoneally administered vehicle, ONO-8590580 (10 mg/kg), or FG-7142 $(10 \mathrm{mg} / \mathrm{kg})$. After 30 minutes, the mice were infused with a $15 \mathrm{mg} / \mathrm{ml} \mathrm{PTZ} \mathrm{solution} \mathrm{(infusion} \mathrm{rate,} 0.2 \mathrm{ml} / \mathrm{min}$ ) and the time taken to reveal clonic seizures was measured, and from this the dose administered was calculated.

Statistical Analysis. Except where noted, data are expressed as the mean \pm S.E.M. Statistical analyses were performed using SAS version 9.2 TS2M3 (SAS Institute Japan Inc., Tokyo, Japan) and its cooperative system EXSUS version 7.7.1 (CAC Corporation, Tokyo, Japan) with Student's $t$ test, Wilcoxon rank-sum test, Dunnett's test, or Steel test, as appropriate. Tests were two sided and conducted at a $5 \%$ level of significance.

\section{Results}

In Vitro Binding of ONO-8590580 to GABA Receptors. Inhibition of $\left[{ }^{3} \mathrm{H}\right]-\mathrm{Ro} 15-4513$ binding showed that ONO8590580 binds with high affinity to $\mathrm{GABA}_{\mathrm{A}} \alpha 5\left(K_{\mathrm{i}}=7.9 \mathrm{nM}\right)$ (Fig. 2). The inhibition of $\left[{ }^{3} \mathrm{H}\right]-\mathrm{Ro} 15-1788$ binding showed that ONO-8590580 also binds to $\mathrm{GABA}_{\mathrm{A}} \alpha 1, \alpha 2$, and $\alpha 3$ with $K_{\mathrm{i}}$ values of 140,32 , and $24 \mathrm{nM}$, respectively (Fig. 2).

Efficacy of ONO-8590580 on Each Subtype of GABA Receptors. ONO-8590580 concentration-dependently inhibited the current induced by the $\mathrm{EC}_{20}$ concentration of GABA in human $\mathrm{GABA}_{\mathrm{A}} \alpha 5 \beta 3 \gamma 2$ expressing the HEK293 cell line (Fig. 3). The calculated maximum inhibition was $-44.4 \%$, and the $\mathrm{EC}_{50}$ and Hill slope values were $-1.1 \mathrm{nM}$ and -0.50 , respectively. ONO8590580 was not effective or only slightly effective in $\mathrm{GABA}_{\mathrm{A}} \alpha 1$, $\alpha 2$, and $\alpha 3$ (Fig. 3).

Effect on LTP in Rat Hippocampal Slice. LTP was induced using a standard paradigm that involves a $\theta$-burst stimulus (Fig. 4). In control experiments, the fEPSP slopes were enhanced after the $\theta$-burst compared with the baseline, then returned to baseline 1 hour after stimulation. In the presence of ONO-8590580 (300 $\mathrm{nM})$, the slopes after the $\theta$-burst were also enhanced compared with the baseline, but did not return to baseline values 1 hour after stimulation. Therefore, ONO-8590580 significantly induced LTP after a $\theta$-burst in the CA1.
In Vivo Receptor Occupancy in Rat Hippocampus. ONO-8590580 competed the binding of $\left[{ }^{3} \mathrm{H}\right]-\mathrm{R} 015-4513$, a $\mathrm{GABA}_{\mathrm{A}} \alpha 5$ specific binder, in the rat hippocampus after oral administration (Fig. 5). The ratio of $\mathrm{GABA}_{\mathrm{A}} \alpha 5$ occupancy values produced by ONO-8590580 at $1,3,10$, and $20 \mathrm{mg} / \mathrm{kg}$ were $44 \%, 53 \%, 71 \%$, and $89 \%$, respectively. The $\mathrm{ED}_{50}$ value of ONO-8590580 with $95 \%$ confidence intervals was $1.9 \mathrm{mg} / \mathrm{kg}$ (1.0 $2-3.72 \mathrm{mg} / \mathrm{kg})$.

Effect on MK-801-Induced Cognitive Deficit in Passive Avoidance Test. MK-801 (a NMDA antagonist)treated rodents have been validated as an animal model of cognitive dysfunction associated with dementia (van der Staay et al., 2011). It is reported that negative modulation of $\mathrm{GABA}_{\mathrm{A}}$ $\alpha 5$ in rats partially prevents the memory impairment induced by MK-801 (Timić Stamenić et al., 2015). Therefore, we evaluated the effect of ONO-8590580 on MK-801-induced cognitive deficit in the passive avoidance test. The latencies in the acquisition trial did not significantly differ regardless of the treatment administered 1 hour before the trial (data not shown). ONO-8590580 (3, 10, and $20 \mathrm{mg} / \mathrm{kg}$ ) significantly increased the escape latency compared with control in the retention trial (Fig. 6).

Effect on MK-801/Scopolamine-Induced Cognitive Deficit in Eight-Arm Radial Maze Test. Patients with $\mathrm{AD}$ have both cholinergic neuron degeneration (Everitt and Robbins, 1997; Schliebs and Arendt, 2006) and hypofunction of glutamatergic neurotransmission (Hardy et al., 1987; Lin et al., 2014) in the brain. Therefore, the cognitive deficit in rats induced by the combination of scopolamine, a muscarinic antagonist, and MK- 801 would be useful as a model of $\mathrm{AD}$ dementia. We investigated the effect of ONO-8590580 on the MK-801/scopolamine-induced cognitive deficit in the eightarm radial maze test, as described by Li et al. (1996). Doses of MK-801 and scopolamine for this test were 0.075 (i.p.) and $0.2 \mathrm{mg} / \mathrm{kg}$ (i.p.), respectively, because we confirmed that each single administration at these doses increased the number of errors respectively, and that in combination there was a stronger effect than for each single administration (data not shown). As a positive control and for comparison purposes, a $0.5 \mathrm{mg} / \mathrm{kg}$ dose of donepezil (p.o.), which decreases both the number of errors and the running time in the scopolamineinduced cognitive deficit in the eight-arm radial maze test (Sugimoto et al., 2002), was also evaluated. ONO-8590580 $(20 \mathrm{mg} / \mathrm{kg}$, p.o.) significantly decreased the number of errors and the total latency compared with the control (Fig. 7).
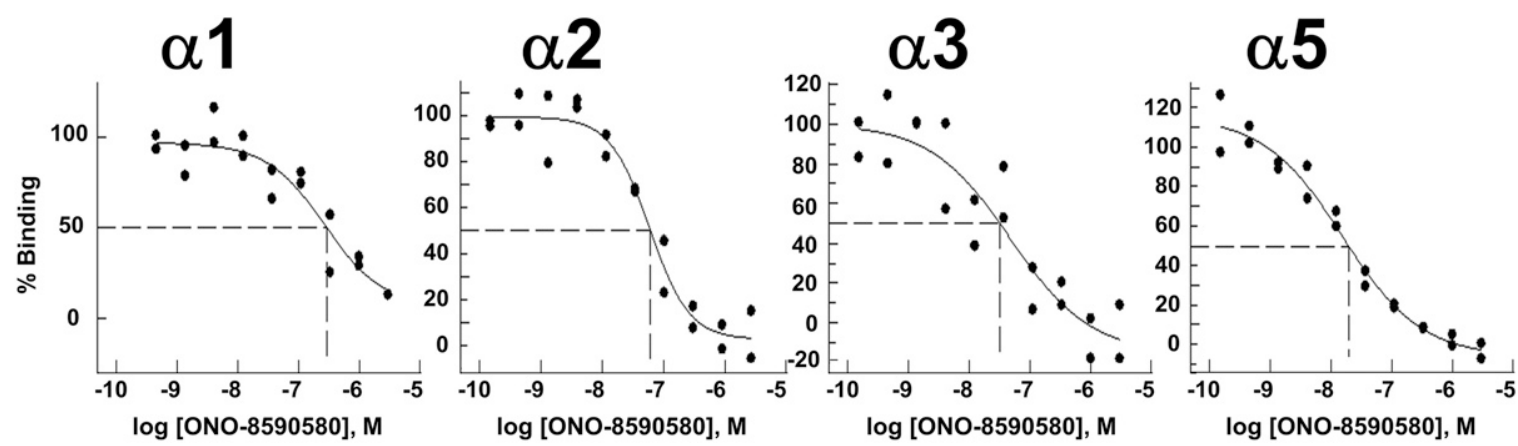

Fig. 2. In vitro binding affinity of ONO- 8590580 at human recombinant $\mathrm{GABA}_{\mathrm{A}}$ receptors. HEK293 cell lines stably expressing human GABA $\alpha 1, \alpha 2$, $\alpha 3$, and $\alpha 5 \beta 3 \gamma 2$ were used in an SPA. Affinity at $\mathrm{GABA}_{\mathrm{A}} \alpha 1, \alpha 2$, and $\alpha 3$ was measured using a [ $\left.{ }^{3} \mathrm{H}\right]-\mathrm{Ro} 15-1788$ binding assay, whereas affinity at GABA $\mathrm{A}_{\mathrm{A}}$ $\alpha 5$ was measured using $\left[{ }^{3} \mathrm{H}\right]-\mathrm{Ro} 15-4513$. 


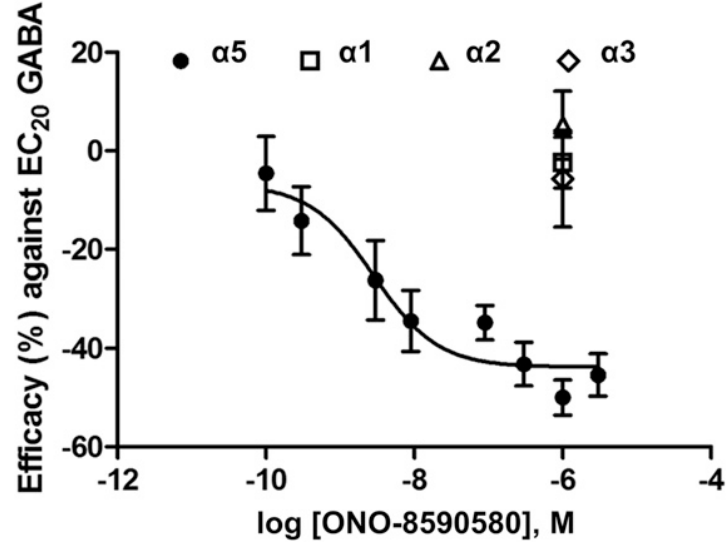

Fig. 3. Efficacy of ONO-8590580 on human recombinant $\mathrm{GABA}_{\mathrm{A}}$ receptors. HEK-293 cell lines stably expressing human $\mathrm{GABA}_{\mathrm{A}} \alpha 1, \alpha 2$, $\alpha 3,(n=3)$, and $\alpha 5 \beta 3 \gamma 2(n=5)$ were used in a patch-clamp study. The ability of ONO-8590580 to attenuate or potentiate the current induced by the $\mathrm{EC}_{20}$ concentration of GABA was assessed by whole-cell patch-clamp electrophysiology. Data are expressed as the mean and S.E.M.

Donepezil (0.5 mg/kg, p.o.) also decreased total latency, but not the number of errors compared with the control.

Effect in Elevated Plus Maze Test and PTZ Test. In the rat elevated plus maze test, the nonselective $\mathrm{GABA}_{\mathrm{A}} \mathrm{NAM}$ FG-7142 significantly decreased the time spent on the open arms, whereas ONO-8590580 had no effect compared with vehicle-treated animals (Fig. 8A).

In the mouse PTZ test, FG-7142 decreased the dose of PTZ required to induce clonic seizure, whereas ONO-8590580 had no effect on the threshold for PTZ-induced clonic seizure (Fig. 8B).

\section{Discussion}

The present study demonstrated that ONO-8590580, a functionally selective $\mathrm{GABA}_{\mathrm{A}} \alpha 5 \mathrm{NAM}$, significantly enhanced LTP in rat hippocampal slices and improved cognitive deficits in rats without anxiogenic-like or proconvulsant effects.

ONO-8590580 has only 3.3-17.7 times higher binding selectivity for $\mathrm{GABA}_{\mathrm{A}} \alpha 5$ compared with $\mathrm{GABA}_{\mathrm{A}} \alpha 1, \alpha 2$, and $\alpha 3$, but it shows very high functional selectivity for $\mathrm{GABA}_{\mathrm{A}} \alpha 5$. This in vitro profile is similar to those for $\alpha 5$ IA (Dawson et al., 2006) and MRK-016 (Atack et al., 2009), but differs from that of RO4938581, which has both binding selectivity and function selectivity for $\mathrm{GABA}_{\mathrm{A}} \alpha 5$ (Ballard et al., 2009). It is not known whether compounds display different phenotypes in vivo depending on the presence or absence of binding selectivity to $\mathrm{GABA}_{\mathrm{A}} \alpha 5$. It is reported that there are endogenous ligands to the BZ binding site: endozepines (Farzampour et al., 2015). This finding indicates that different phenotypes may be shown by each compound with and without binding selectivity. Among 82 off-target agents, ONO-8590580 bound only to the adenosine A3 receptor with an inhibition of $68 \%$ at a drug concentration of $10 \mu \mathrm{M}$; thus, ONO-8590580 is highly selective for $\mathrm{GABA}_{\mathrm{A}} \alpha 5$ (Eurofins Panlabs Inc., Taipei, Taiwan; data not shown).

The physiologic properties of hippocampal-related cognitive process may involve long-term changes in synaptic efficacy, such as in LTP (Bliss and Collingridge, 1993). Nonselective
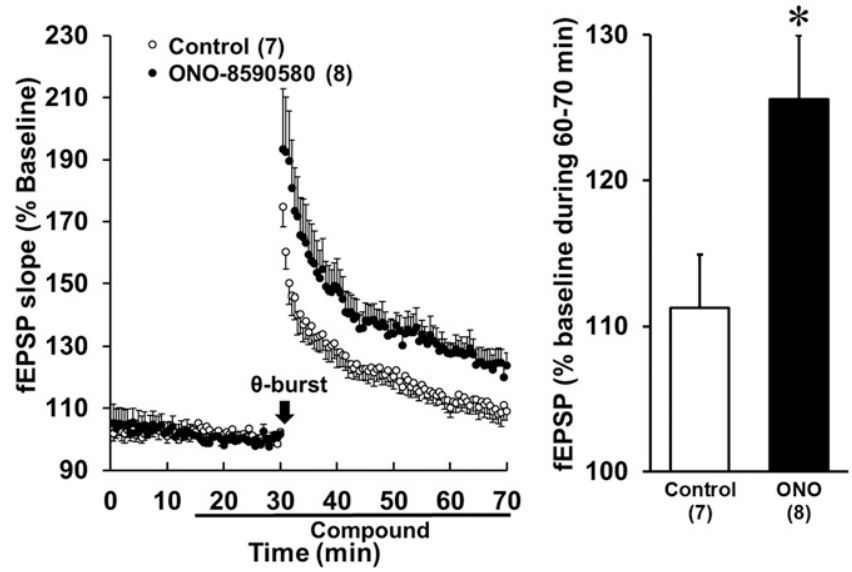

Fig. 4. Effect of ONO-8590580 (300 nM) on LTP in rat hippocampal slice. The fEPSPs in response to stimulation of the Schaffer collateralcommissural pathway were recorded. To produce LTP, a $\theta$-burst protocol (four pulses delivered with a frequency of $100 \mathrm{~Hz}$, repeated 10 times with an interval of 200 milliseconds) was used. Data are expressed as the mean and S.E.M. ( $n=7-8$ slices). ${ }^{*} P<0.05$ compared with the control group (Student's $t$ test). ONO, ONO-8590580.

GABA $_{\mathrm{A}}$ NAMs increase LTP (Seabrook et al., 1997), whereas

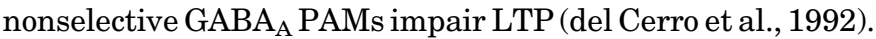
In this study, the selective $\mathrm{GABA}_{\mathrm{A}} \alpha 5$ NAM enhanced LTP after a $\theta$-burst in a rat hippocampal slice. This result is consistent with other reports showing that other $\mathrm{GABA}_{\mathrm{A}} \alpha 5$ NAMs enhance LTP (Dawson et al., 2006; Atack et al., 2009; Ballard et al., 2009). Etomidate, which has memory-blocking properties, inhibited LTP, and this effect was reversed by

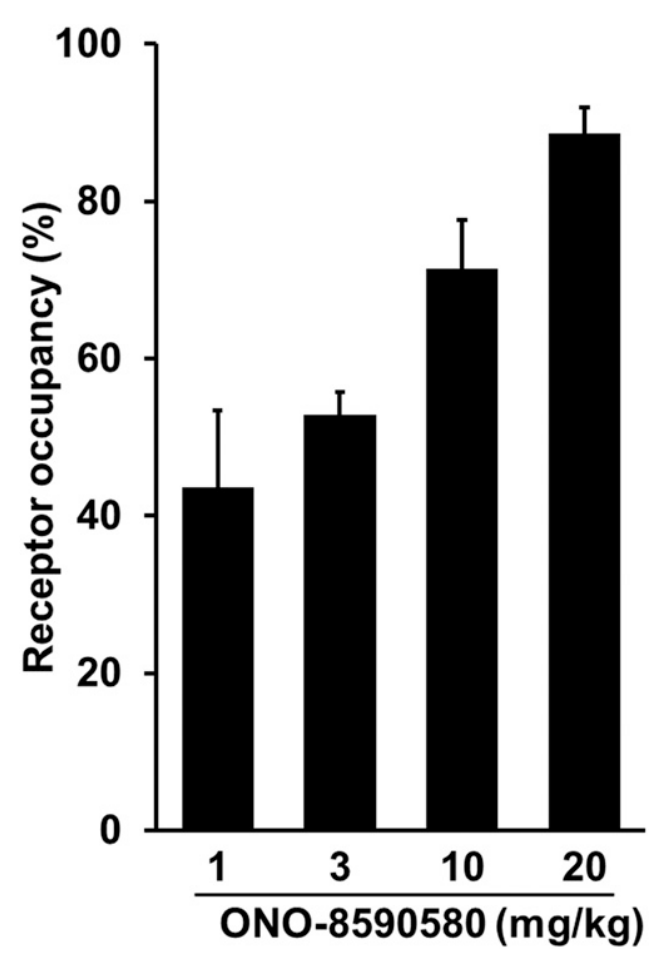

Fig. 5. Receptor occupancy of ONO-8590580 on rat hippocampal GABA $\alpha 5$. ONO-8590580 at $1,3,10$, and $20 \mathrm{mg} / \mathrm{kg}$ was orally administered 1 hour before sacrifice. $\left[{ }^{3} \mathrm{H}\right]-$ Ro $15-4513$ was intravenously administered $10 \mathrm{~min}$ utes before sacrificing the rats. Data are expressed as the mean and S.E. M. $(n=3-4)$ 
(10) (15) (15) (15) (15) (15)

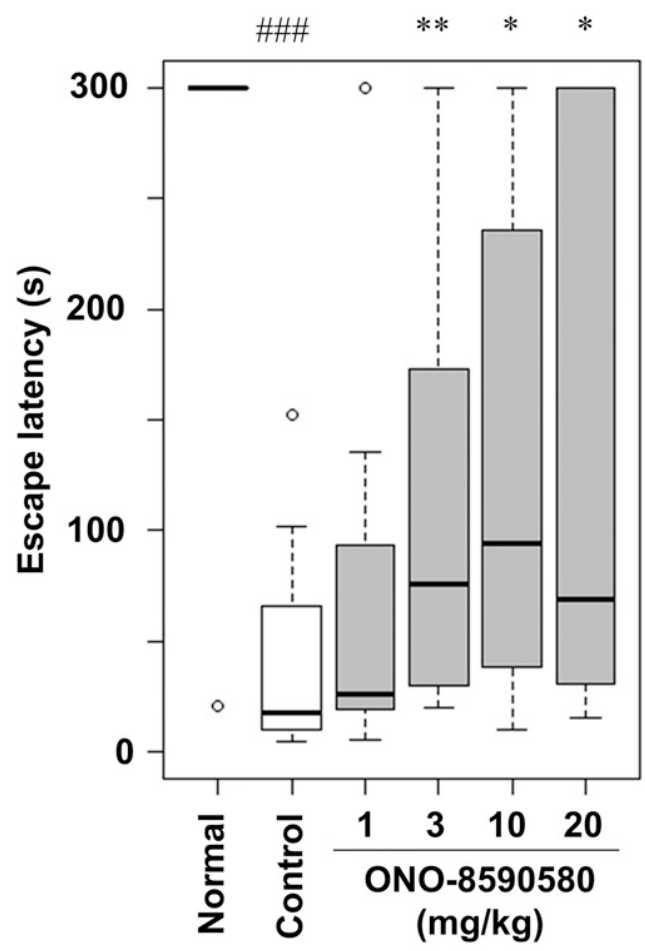

Fig. 6. Effect on MK-801-induced cognitive deficit in rat passive avoidance test. On day 1 (acquisition trial), MK- $801(0.1 \mathrm{mg} / \mathrm{kg}$, s.c.) was administered to rats 30 minutes before the trial. A retention trial was conducted 24 hours after the acquisition trial. Vehicle or ONO-8590580 was orally administered 1 hour before the acquisition and retention trial. Data are represented by box plot $(n=10-15$ in each group). \#\#\#P<0.001 compared with Normal group (Wilcoxon rank-sum test). $* P<0.05$; $* * P<$ 0.01 compared with the control group (Steel test).

L-655,708 (Martin et al., 2009). These findings indicate that $\mathrm{GABA}_{\mathrm{A}} \alpha 5$ holds an important role for the enhanced LTP observed with nonselective $\mathrm{GABA}_{\mathrm{A}}$ NAMs. GABA $\alpha 5$ is predominantly localized to extrasynaptic space in the hippocampus (Farrant and Nusser, 2005; Brickley and Mody, 2012). It has been reported that tonic inhibition mediated by $\mathrm{GABA}_{\mathrm{A}}$ $\alpha 5$ affects the induction and maintenance of LTP (Ge et al.,
2008; Martin et al., 2010; Li et al., 2012). Since ONO-8590580 inhibits the function of $\mathrm{GABA}_{\mathrm{A}} \alpha 5$, tonic inhibition may be suppressed and LTP may be consequently enhanced.

ONO-8590580 significantly improved MK-801-induced cognitive deficit in the rat passive avoidance test. MK-801 impairs contextual specificity of hippocampal immediateearly gene expression, which is critical for the maintenance of synaptic plasticity and memory consolidation (Kubik et al., 2014). $\mathrm{GABA}_{\mathrm{A}} \alpha 5$ is expressed in the bases of the spines and the adjacent shafts of the dendrites (Fritschy and Brünig, 2003), and modulates the excitatory input arising at the spines via NMDA receptor (Glykys et al., 2008; Brickley and Mody, 2012). Therefore, it is suggested that ONO-8590580 improved MK-801-induced cognitive impairment indirectly via enhancing the excitatory input in hippocampal CA1 spines.

In patients with $\mathrm{AD}$, the presence of not only cholinergic neuron degeneration in the nasal forebrain but also hypofunction of NMDA receptor-mediated neurotransmission in cortical and hippocampal regions in postmortem and imaging studies of the brains (Hardy et al., 1987; Bi and Sze, 2002; Lin et al., 2014). Blockage of NMDA receptor-mediated neurotransmission has been reported to prevent the induction of LTP in the hippocampus (Bashir et al., 1991; Seabrook et al., 1997). MK-801 is known to induce memory deficit in animals (Suryavanshi et al., 2014). In addition, the decrease in NMDA receptors in the hippocampus and entorhinal cortex of patients with $\mathrm{AD}$ has been reported to correlate with the disease neuropathological progression, as assessed by postmortem examination (Kravitz et al., 2013). Thus, we used a rat model with cognitive deficit induced by a cotreatment model of muscarinic receptor antagonist scopolamine $(0.2 \mathrm{mg} / \mathrm{kg})$ and the NMDA receptor antagonist MK-801 $(0.075 \mathrm{mg} / \mathrm{kg})$ as a model reflecting a part of $\mathrm{AD}$ dementia in the eight-arm radial maze test. The dose of donepezil that was effective for total latency was $0.5 \mathrm{mg} / \mathrm{kg}$ in this model, but that dose did not improve the number of errors. Donepezil at this dose significantly improves the cognitive deficit induced by scopolamine in 8-arm radial maze test (Sugimoto et al., 2002), and it also improves the cognitive deficit induced by lesions of the medial septum in the water maze test more effectively at a dose of $0.5 \mathrm{mg} / \mathrm{kg}$ than at $2 \mathrm{mg} / \mathrm{kg}$ (Ogura et al., 2000). Therefore,
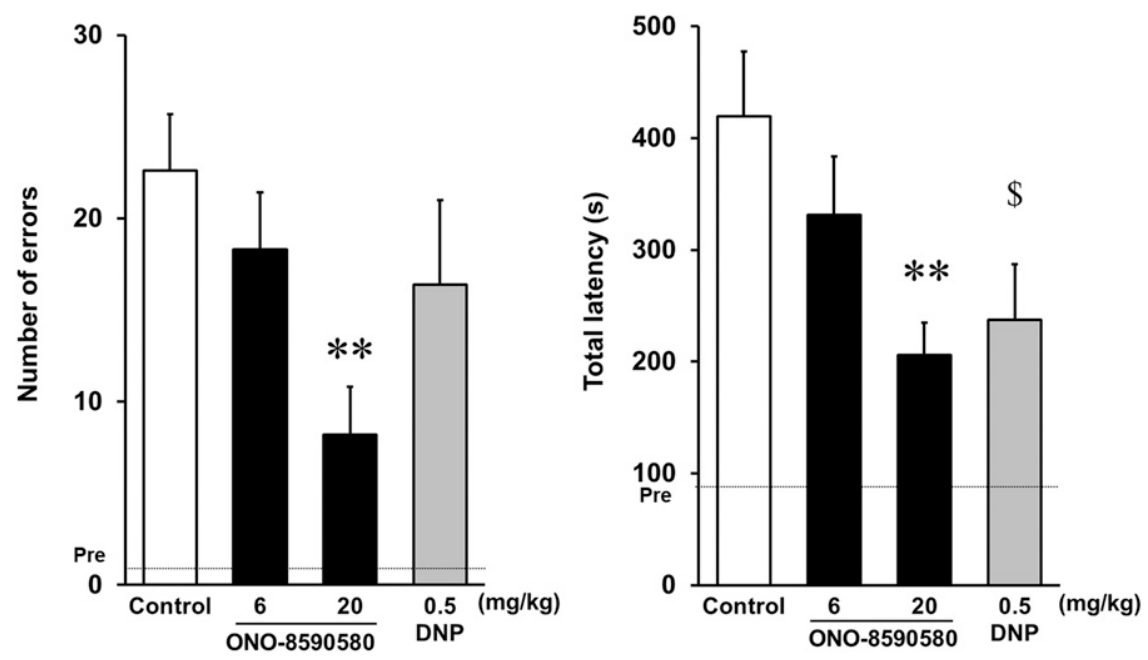

Fig. 7. Effect on MK-801/scopolamine-induced cognitive deficit in the rat eight-arm radial maze test. Vehicle, ONO-8590580, or donepezil (DNP) was administered orally 1 hour before the trial. MK-801 $(0.05 \mathrm{mg} / \mathrm{kg})$ and scopolamine $(0.15 \mathrm{mg} / \mathrm{kg})$ were administered subcutaneously 0.5 hour before the test trial. The number of errors and the latency until the bait of all eight wells had been consumed were counted. Data are expressed as the mean and S.E.M. ( $n=10$ in each group). $* * P<0.01$ compared with the control group (Dunnett test). $\$ P<0.05$ compared with the control group (Student's $t$ test). 

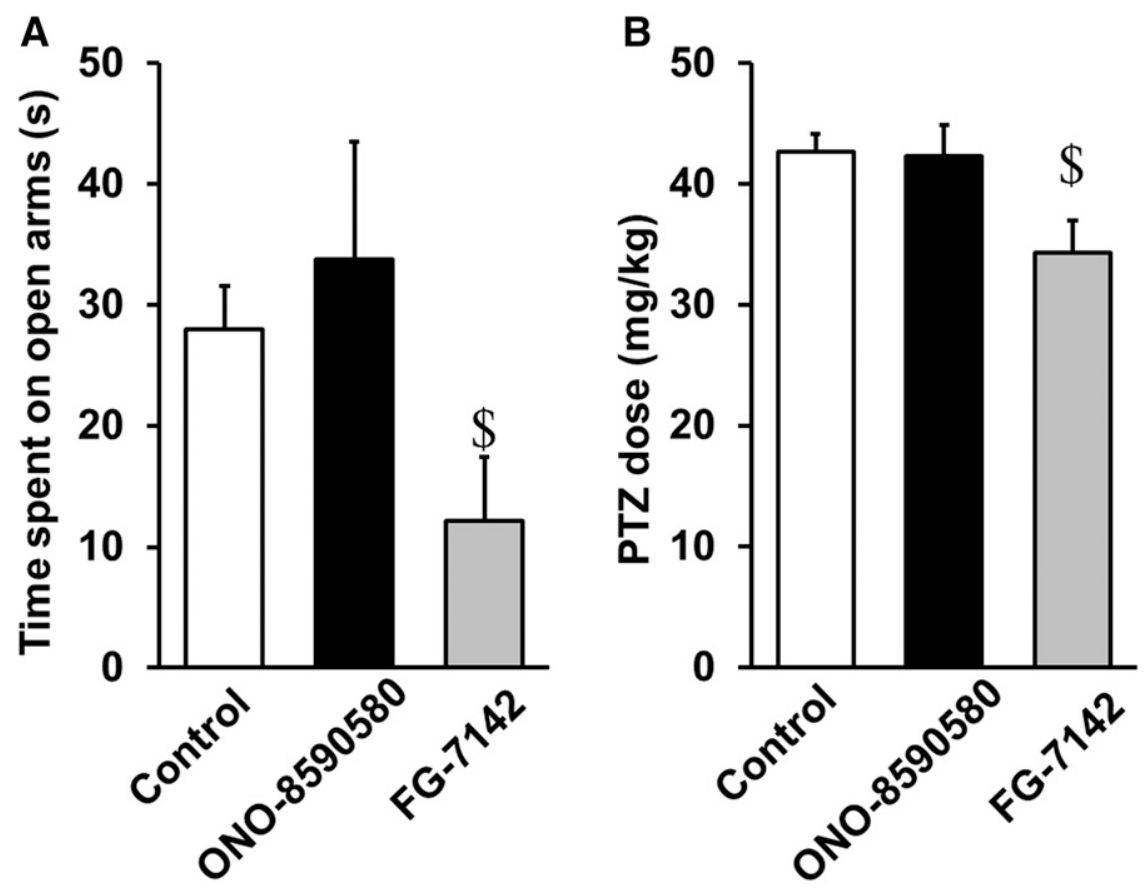

Fig. 8. No anxiogenic-like effect in the rat elevated plus maze test (A) and no proconvulsant effect in the mouse PTZ test (B). (A) Vehicle (p.o.), ONO-8590580 $(20 \mathrm{mg} / \mathrm{kg}$, p.o.), or FG-7142 (15 mg/kg, i.p.) was administered 1 hour before the test. One hour after administration, rats were given a 5-minute trial on the elevated plus maze, and the time spent on the open arm was calculated. (B) Vehicle (i.p.), ONO8590580 (10 mg/kg, i.p.), or FG-7142 (10 mg/kg, i.p.) was administered 30 minutes before the test. Mice were infused intravenously with PTZ via the tail vein. Data are expressed as the mean and S.E.M. $(n=$ 12 in each group in elevated plus maze test, $n=8$ in each group in PTZ test). $\$ P<0.05$ compared with the control group (Student's $t$ test).

$0.5 \mathrm{mg} / \mathrm{kg}$ donepezil is an appropriate dose to investigate the efficacy of donepezil. The present study in which ONO8590580 , but not donepezil, significantly decreased the number of errors may suggest that ONO-8590580 could be more potent for the treatment of patients with $\mathrm{AD}$. The data showing that ONO-8590580 has no anxiogenic-like or proconvulsant effects are in agreement with the behavioral phenotype of $\alpha 5^{-/-}$mice (Collinson et al., 2002).

The receptor occupancy was $44 \%, 53 \%, 71 \%$, and $89 \%$ at 1,3 , 10 , and $20 \mathrm{mg} / \mathrm{kg}$ (p.o.), respectively. The effective doses of ONO-8590580 were $3-20 \mathrm{mg} / \mathrm{kg}$ (p.o.) in the passive avoidance test and $20 \mathrm{mg} / \mathrm{kg}$ (p.o.) in the eight-arm radial maze test. Axiogenic-like and proconvulsant effects were not observed at $20 \mathrm{mg} / \mathrm{kg}$ (p.o.) and $10 \mathrm{mg} / \mathrm{kg}$ (i.p.), respectively. From these results, the target level of occupancy for clinical studies might be $53 \%-89 \%$.

In the brains of patients with $\mathrm{AD}$, the number of reactive astrocytes increase (Jo et al., 2014) and phenotypically switch from GABA negative to GABA producing (Oh and Lee, 2017). Released GABA from reactive astrocytes to the extracellular space activates $\mathrm{GABA}_{\mathrm{A}} \alpha 5$ and induces tonic inhibition (Farrant and Nuzzer, 2005; Kim et al., 2017). Tonic inhibition may suppress the activity of excitatory neurons in the hippocampus, decrease LTP, and impair learning and memory (Ge et al., 2008; Martin et al., 2010; Li et al., 2012). In accordance with previous findings (Dawson et al., 2006; Atack et al., 2009; Ballard et al., 2009 ), this study confirmed that a $\mathrm{GABA}_{\mathrm{A}} \alpha 5 \mathrm{NAM}$ increases LTP and improves learning and memory. In addition, the GABA $_{\mathrm{A}} \alpha 5$ expression level in hippocampus increases in patients with $\mathrm{AD}$ (Kwakowsky et al., 2018). These results suggest that astrocytic GABA and extrasynaptic $\mathrm{GABA}_{\mathrm{A}} \alpha 5$ are important players in the pathogenesis of $\mathrm{AD}$, and that $\mathrm{ONO}$ 8590580, a GABA $\alpha 5$ NAM, is an attractive agent with which to treat $\mathrm{AD}$. Since reactive astrocytes have also been described in patients with Parkinson disease, stroke, epilepsy, brain trauma, and other neurodegenerative diseases (Luchetti et al., 2011; Brichta et al., 2013), ONO-8590580 could also be considered for the treatment of such neurodegenerative diseases as well as AD. Future work is needed to explore these exciting possibilities.

The development of another chemotype of $\mathrm{GABA}_{\mathrm{A}} \alpha 5 \mathrm{NAM}$, $\alpha 5 \mathrm{IA}$, was discontinued because of preclinical renal toxicity (Atack, 2010), and MRK-016 was poorly tolerated in the elderly volunteers (Atack, 2011). A clinical trial of RG1662 was conducted in subjects with Down syndrome (Costa and Scott-McKean, 2013), but there is no information in patients with $\mathrm{AD}$.

We have shown in this study that ONO-8590580, a novel $\mathrm{GABA}_{\mathrm{A}} \alpha 5$ NAM, will improve cognitive impairment without anxiogenic or proconvulsant side effects. These findings indicate that ONO-8590580 could be beneficial for preclinically evaluating cognitive disorders like $\mathrm{AD}$.

\section{Authorship Contributions}

Participated in research design: Kawaharada, Yasuhiro, Clark, Maidment, Katsumata, and Kaneko.

Conducted experiments: Kawaharada, M. Nakanishi, N. Nakanishi, Hazama, Clark, and Maidment.

Contributed new reagents or analytic tools: Higashino, Lewis, and Chambers.

Performed data analysis: Kawaharada, M. Nakanishi, N. Nakanishi, Hazama, Clark, and Maidment.

Wrote or contributed to the writing of the manuscript: Kawaharada, Katsumata, and Kaneko.

\section{References}

Akagi M, Matsui N, Akae H, Hirashima N, Fukuishi N, Fukuyama Y, and Akagi R (2015) Nonpeptide neurotrophic agents useful in the treatment of neurodegenerative diseases such as Alzheimer's disease. J Pharmacol Sci 127:155-163.

Atack JR (2010) Preclinical and clinical pharmacology of the GABAA receptor alpha5 subtype-selective inverse agonist alpha5IA. Pharmacol Ther 125:11-26.

Atack JR (2011) GABAA receptor subtype-selective modulators. II. $\alpha 5$-selective inverse agonists for cognition enhancement. Curr Top Med Chem 11:1203-1214.

Atack JR, Hutson PH, Collinson N, Marshall G, Bentley G, Moyes C, Cook SM, Collins I, Wafford K, McKernan RM, et al. (2005) Anxiogenic properties of an inverse agonist selective for alpha3 subunit-containing GABA A receptors. $\mathrm{Br} J$ Pharmacol 144:357-366.

Atack JR, Maubach KA, Wafford KA, O'Connor D, Rodrigues AD, Evans DC, Tattersall FD, Chambers MS, MacLeod AM, Eng WS, et al. (2009) In vitro and in vivo 
properties of 3-tert-butyl-7-(5-methylisoxazol-3-yl)-2-(1-methyl-1H-1,2,4-triazol-5ylmethoxy) -pyrazolo[1,5-d]-[1,2,4]triazine (MRK-016), a GABAA receptor alpha5 subtype-selective inverse agonist. J Pharmacol Exp Ther 331:470-484.

Ballard TM, Knoflach F, Prinssen E, Borroni E, Vivian JA, Basile J, Gasser R, Moreau JL, Wettstein JG, Buettelmann B, et al. (2009) RO4938581, a novel cognitive enhancer acting at GABAA alpha5 subunit-containing receptors. Psychopharmacology (Berl) 202:207-223.

Bashir ZI, Alford S, Davies SN, Randall AD, and Collingridge GL (1991) Long-term potentiation of NMDA receptor-mediated synaptic transmission in the hippocampus. Nature 349:156-158

Bi H and Sze CI (2002) N-methyl-D-aspartate receptor subunit NR2A and NR2B messenger RNA levels are altered in the hippocampus and entorhinal cortex in Alzheimer's disease. J Neurol Sci 200:11-18.

Bliss TV and Collingridge GL (1993) A synaptic model of memory: long-term potentiation in the hippocampus. Nature 361:31-39.

Brichta L, Greengard P, and Flajolet M (2013) Advances in the pharmacological treatment of Parkinson's disease: targeting neurotransmitter systems. Trends Neurosci 36:543-554.

Brickley SG and Mody I (2012) Extrasynaptic GABA(A) receptors: their function in the CNS and implications for disease. Neuron 73:23-34.

Cheng Y and Prusoff WH (1973) Relationship between the inhibition constant (K1) and the concentration of inhibitor which causes 50 per cent inhibition (I50) of an enzymatic reaction. Biochem Pharmacol 22:3099-3108.

Collinson N, Kuenzi FM, Jarolimek W, Maubach KA, Cothliff R, Sur C, Smith A, Otu FM, Howell O, Atack JR, et al. (2002) Enhanced learning and memory and altered GABAergic synaptic transmission in mice lacking the alpha 5 subunit of the GABAA receptor. $J$ Neurosci 22:5572-5580.

Costa AC and Scott-McKean JJ (2013) Prospects for improving brain function in individuals with Down syndrome. CNS Drugs 27:679-702.

Dawson GR, Maubach KA, Collinson N, Cobain M, Everitt BJ, MacLeod AM, Choudhury HI, McDonald LM, Pillai G, Rycroft W, et al. (2006) An inverse agonist selective for alpha5 subunit-containing GABAA receptors enhances cognition. $J$ Pharmacol Exp Ther 316:1335-1345.

del Cerro S, Jung M, and Lynch G (1992) Benzodiazepines block long-term potentiation in slices of hippocampus and piriform cortex. Neuroscience 49:1-6.

Dorow R, Horowski R, Paschelke G, and Amin M (1983) Severe anxiety induced by FG 7142, a beta-carboline ligand for benzodiazepine receptors. Lancet 2:98-99.

Everitt BJ and Robbins TW (1997) Central cholinergic systems and cognition. Annu Rev Psychol 48:649-684.

Farlow MR, Miller ML, and Pejovic V (2008) Treatment options in Alzheimer's disease: maximizing benefit, managing expectations. Dement Geriatr Cogn Disord 25:408-422.

Farrant M and Nusser Z (2005) Variations on an inhibitory theme: phasic and tonic activation of GABA(A) receptors. Nat Rev Neurosci 6:215-229.

Farzampour Z, Reimer RJ, and Huguenard J (2015) Endozepines. Adv Pharmacol 72: $147-164$.

Fritschy JM and Brünig I (2003) Formation and plasticity of GABAergic synapses physiological mechanisms and pathophysiological implications. Pharmacol Ther 98:299-323.

Ge S, Sailor KA, Ming GL, and Song H (2008) Synaptic integration and plasticity of new neurons in the adult hippocampus. J Physiol 586:3759-3765

Glykys J, Mann EO, and Mody I (2008) Which GABAA receptor subunits are necessary for tonic inhibition in the hippocampus? J Neurosci 28:1421-1426.

Hadingham KL, Wingrove P, Le Bourdelles B, Palmer KJ, Ragan CI, and Whiting PJ (1993) Cloning of cDNA sequences encoding human alpha 2 and alpha 3 gammaaminobutyric acidA receptor subunits and characterization of the benzodiazepine pharmacology of recombinant alpha 1-, alpha 2-, alpha 3-, and alpha 5-containing human gamma-aminobutyric acidA receptors. Mol Pharmacol 43:970-975.

Haefely WE, Martin JR, Richards JG, and Schoch P (1993) The multiplicity of actions of benzodiazepine receptor ligands. Can J Psychiatry 38 (Suppl 4):S102-S108.

Hardy J, Cowburn R, Barton A, Reynolds G, Dodd P, Wester P, O'Carroll AM, Lof dahl E, and Winblad B (1987) A disorder of cortical GABAergic innervation in Alzheimer's disease. Neurosci Lett 73:192-196.

Horowski R and Dorrow R (2002) Anxiogenic, not psychotogenic, properties of the partial inverse benzodiazepine receptor agonist FG 7142 in man. Psychopharmacology (Berl) 162.223-224.

Jo S, Yarishkin O, Hwang YJ, Chun YE, Park M, Woo DH, Bae JY, Kim T, Lee J, Chun H, et al. (2014) GABA from reactive astrocytes impairs memory in mouse models of Alzheimer's disease. Nat Med 20:886-896.

Kim YS, Woo J, Lee CJ, and Yoon BE (2017) Decreased glial GABA and tonic inhibition in cerebellum of mouse model for Attention-Deficit/Hyperactivity Disorder (ADHD). Exp Neurobiol 26:206-212.

Kravitz E, Gaisler-Salomon I, and Biegon A (2013) Hippocampal glutamate NMDA receptor loss tracks progression in Alzheimer's disease: quantitative autoradiography in postmortem human brain. PLoS One 8:e81244.

Kubík S, Buchtová H, Valeš K, and Stuchlík A (2014) MK-801 impairs cognitive coordination on a rotating arena (carousel) and contextual specificity of hippocampal immediate-early gene expression in a rat model of psychosis. Front Behav Neurosci 8:75.

Kwakowsky A, Calvo-Flores Guzmán B, Pandya M, Turner C, Waldvogel HJ, and Faull RL (2018) GABAA receptor subunit expression changes in the human
Alzheimer's disease hippocampus, subiculum, entorhinal cortex and superior temporal gyrus. $J$ Neurochem [published ahead of print].

Li HB, Matsumoto K, Tohda M, Yamamoto M, and Watanabe H (1996) NMDA-but not AMPA-receptor antagonists augment Scopolamine-induced spatial cognitive deficit of rats in a radial maze task. Brain Res 725:268-271.

Li Y, Aimone JB, Xu X, Callaway EM, and Gage FH (2012) Development of GABAergic inputs controls the contribution of maturing neurons to the adult hippocampal network. Proc Natl Acad Sci USA 109:4290-4295.

Lin CH, Huang YJ, Lin CJ, Lane HY, and Tsai GE (2014) NMDA neurotransmission dysfunction in mild cognitive impairment and Alzheimer's disease. Curr Pharm Des 20:5169-5179.

Luchetti S, Bossers K, Van de Bilt S, Agrapart V, Morales RR, Frajese GV, and Swaab DF (2011) Neurosteroid biosynthetic pathways changes in prefrontal cortex in Alzheimer's disease. Neurobiol Aging 32:1964-1976.

Martin LJ, Oh GH, and Orser BA (2009) Etomidate targets alpha5 gammaaminobutyric acid subtype A receptors to regulate synaptic plasticity and memory blockade. Anesthesiology 111:1025-1035.

Martin LJ, Zurek AA, MacDonald JF, Roder JC, Jackson MF, and Orser BA (2010) Alpha5GABAA receptor activity sets the threshold for long-term potentiation and constrains hippocampus-dependent memory. J Neurosci 30:5269-5282.

McKernan RM, Rosahl TW, Reynolds DS, Sur C, Wafford KA, Atack JR, Farrar S, Myers J, Cook G, Ferris P, et al. (2000) Sedative but not anxiolytic properties of benzodiazepines are mediated by the $\mathrm{GABA}(\mathrm{A})$ receptor alpha1 subtype. Nat Neurosci 3:587-592.

Mitsui K, Niwa T, Kawahara Y, Morimoto N, Ohmoto K, Kato M, Yamaura Y, Yoshimoto N, Suna H, and Katsumata S (2015) Anti-stress effects of ONO-2952, a novel translocator protein $18 \mathrm{kDa}$ antagonist, in rats. Neuropharmacology 99:51-66.

Ogura H, Kosasa T, Kuriya Y, and Yamanishi Y (2000) Donepezil, a centrally acting acetylcholinesterase inhibitor, alleviates learning deficits in hypocholinergic models in rats. Methods Find Exp Clin Pharmacol 22:89-95.

Oh SJ and Lee CJ (2017) Distribution and function of the bestrophin-1 (Best1) channel in the brain. Exp Neurobiol 26:113-121.

Ohta H, Matsumoto K, and Watanabe H (1993) The interaction between central cholinergic and peripheral beta-adrenergic systems on radial maze performance in rats. Brain Res 622:353-356.

Quirk K, Blurton P, Fletcher S, Leeson P, Tang F, Mellilo D, Ragan CI, and McKernan RM (1996) [3H]L-655,708, a novel ligand selective for the benzodiazepine site of GABAA receptors which contain the alpha 5 subunit. Neuropharmacology 35:1331-1335.

Rudolph U, Crestani F, Benke D, Brünig I, Benson JA, Fritschy JM, Martin JR, Bluethmann H, and Möhler H (1999) Benzodiazepine actions mediated by specific gamma-aminobutyric acid(A) receptor subtypes. Nature 401:796-800.

Rudolph U and Möhler H (2004) Analysis of GABAA receptor function and dissection of the pharmacology of benzodiazepines and general anesthetics through mouse genetics. Annu Rev Pharmacol Toxicol 44:475-498.

Samakashvili S, Ibáñez C, Simó C, Gil-Bea FJ, Winblad B, and Cedazo-Mínguez A (2011) Analysis of chiral amino acids in cerebrospinal fluid samples linked to different stages of Alzheimer disease. Electrophoresis 32:2757-2764.

Schliebs R and Arendt T (2006) The significance of the cholinergic system in the brain during aging and in Alzheimer's disease. J Neural Transm (Vienna) 113:1625-1644.

Seabrook GR, Easter A, Dawson GR, and Bowery BJ (1997) Modulation of long-term potentiation in CA1 region of mouse hippocampal brain slices by GABAA receptor benzodiazepine site ligands. Neuropharmacology 36:823-830.

Sugimoto H, Ogura H, Arai Y, Limura Y, and Yamanishi Y (2002) Research and development of donepezil hydrochloride, a new type of acetylcholinesterase inhibitor. Jpn J Pharmacol 89:7-20.

Suryavanshi PS, Ugale RR, Yilmazer-Hanke D, Stairs DJ, and Dravid SM (2014) GluN2C/GluN2D subunit-selective NMDA receptor potentiator CIQ reverses MK-801-induced impairment in prepulse inhibition and working memory in Y-maze test in mice. $\mathrm{Br} J$ Pharmacol 171:799-809.

Timić Stamenić T, Joksimović S, Biawat P, Stanković T, Marković B, Cook JM, and Savić MM (2015) Negative modulation of $\alpha 5$ GABAA receptors in rats may partially prevent memory impairment induced by MK-801, but not amphetamineor MK-801-elicited hyperlocomotion. J Psychopharmacol 29:1013-1024.

Tsukamoto M, Yasui T, Yamada MK, Nishiyama N, Matsuki N, and Ikegaya Y (2003) Mossy fibre synaptic NMDA receptors trigger non-Hebbian long-term potentiation at entorhino-CA3 synapses in the rat. $J$ Physiol 546:665-675.

van der Staay FJ, Rutten K, Erb C, and Blokland A (2011) Effects of the cognition impairer MK-801 on learning and memory in mice and rats. Behav Brain Res 220:215-229.

Vergnes M, Boehrer A, He X, Greney H, Dontenwill M, Cook J, and Marescaux C (2001) Differential sensitivity to inverse agonists of GABA(A)/benzodiazepine receptors in rats with genetic absence-epilepsy. Epilepsy Res 47:43-53.

Wu Z, Guo Z, Gearing M, and Chen G (2014) Tonic inhibition in dentate gyrus impairs long-term potentiation and memory in an Alzheimer's [corrected] disease model [published correction appears in Nat Commun (2014) 5:4810]. Nat Commun 5:4159.

Address correspondence to: Seishi Katsumata, Discovery Research Laboratories I, ONO Pharmaceutical Co., Ltd., 3-1-1 Sakurai, Shimamoto-cho, Mishima-gun, Osaka, 618-8585, Japan. E-mail: s.katsumata@ono.co.jp 